\title{
Photosenzitizer dari Fraksi Metanol: N-Heksana Buah Cabe Merah (Capsiccum Annum L.)
}

\author{
Muh. Shiddiq Maming ${ }^{1}$, Aisyah ${ }^{1}$, Suriani ${ }^{1}$, Iswadi ${ }^{2}$ \\ ${ }^{1} J u r u s a n$ Kimia, Fakultas Sains dan Teknologi, UIN Alauddin Makassar, \\ 2Jurusan Fisika, Fakultas Sains dan Teknologi, UIN Alauddin Makassar \\ Email: aisyah@uin-alauddin.co.id
}

\begin{abstract}
A research has been done on the dye components from the extract of red pepper (Capsiccum annum L) which is potentially used as photosensitizer. This study aims to determine the efficiency and the characteristics of the dye. The efficiency is measured on a cell made of glass ITO $100 \Omega$ and a technical semiconductor $\mathrm{TiO}_{2}$. The pepper extract obtained from the ultrasonic maceration by methanol which then purified using a chromatography column using the ratio of 1 : 4, 1: 1 and 4: 1 methanol:n-hexane. The results showed that the efficiency of the crude extract, fraction by ratio of 1:4; $1: 1$ and $4: 1$ are respectively $0.027 \%, 0.012 \%, 0.013 \%$ and $0.034 \%$. Subsequently, the best efficiency fraction was characterized by using FTIR, UV-Vis and GC-MS. The wavelength of visible light obtained at 466 and $443 \mathrm{~nm}$ which is corresponds to the wavelength of carotene. The components indicate absorption at $1631.78 \mathrm{~cm}^{-1}, 3008.95 \mathrm{~cm}^{-1}$ and $2992 \mathrm{~cm}^{-1}$ that are characteristic of carotenoid whereas, that of $1739 \mathrm{~cm}^{-1}$ and $3446.79 \mathrm{~cm}^{-1}$ are carbonyl and hydroxyl group of xantofil. According to the GC-MS fragmentation pattern, the carotenoid compounds identified by mass abundace at 91 and 105.
\end{abstract}

Keywords: Dye sensitized Solar Cell, photosensitizer, red pepper, ultrasonic maceration

\section{PENDAHUluaN}

Aktivitas masyarakat akan memerlukan pasokan energi yang semakin meningkat dari tahun ke tahun. Oleh karena itu ketersedian energi haruslah menjadi perhatian utama. Di Indonesia, kebutuhan energi mengalami peningkatan setiap tahunnya yang dipicu berbagai aktivitas masyarakat yang memerlukan pasokan energi. Aktivitas masyarakat di berbagai bidang meningkatkan kebutuhan akan energi dari tahun ke tahun hingga sekitar 4,7 \% (IEO, 2012: 4). Sektor industri merupakan sektor dengan konsumsi energi terbanyak yaitu sekitar $33 \%$ diikuti oleh rumah tangga sebesar $27 \%$, transportasi $27 \%$, dan sektor lainnya sekitar $10 \%$ (IEO, 2014: 36).

Suplai energi yang memenuhi kebutuhan nasional dapat diperoleh dari sumber terbarukan dan tidak terbarukan. Penggunaan energi tidak terbarukan masih mendominasi yaitu sebesar 96 $\%$. Energi tidak terbarukan yang berasal dari fosil seperti minyak bumi dengan penggunaan sekitar $48 \%$, gas $18 \%$ dan batu bara $30 \%$ (IEO, 2014: 2) merupakan energi yang sangat terbatas sehingga setiap saat jumlahnya mengalami penurunan. Berbeda halnya dengan energi

Al-Kimia | Volume 5 Nomor $12017 \mid 31$ 
tidak terbarukan, sumber energi terbarukan merupakan sumber daya yang tidak akan pernah habis sehingga penggunaan energi diharapkan beralih pada sumber energi tersebut.

Energi matahari telah dimanfaatkan sebagai penghasil energi listrik dalam bentuk sel surya. Sel surya saat ini memanfaatkan silikon sebagai bahan dasar. Namun sel surya yang berbasis silikon ini merupakan sel surya yang mahal bagi golongan masyarakat bawah. Oleh karena itu dilakukanlah pemanfaatan dari bahan lain seperti zat warna alami. Zat warna dapat digunakan sebagai sel surya dengan mengkombinasikan komponen tertentu seperti bahan titania. Jenis sel surya ini ditemukan oleh Grätzel pada tahun 1991. Sel surya tersebut dikenal sebagai DSSC (Dye-Sensitized Solar Sel). Penggunaan DSSC sebagai sumber energi memiliki beberapa keuntungan seperti ketersediaannya yang banyak dan harganya yang murah.

Tumbuhan seperti cabe merah dapat digunakan sebagai zat warna pada DSSC karena memiliki banyak keuntungan, diantaranya karena cabe Cabe merah terdiri beberapa senyawa warna sepertikarotein. Turunan karotein yang memberi warna merah seperti kapsantin, kasporubin dan kapsantin-5,6-opoksida sedangkan warna jingga berasal dari $\alpha$ dan $\beta$-karoten, xantin, lutein dan $\beta$-kriptoxantin (Maria dan Alejo, 2013:19027).

Selain itu tanaman merupakan tanaman hortikultura yang mengalami peningkatan produksi setiap tahun. Tercatat bahwa dari tahun 2005 hingga 2012 produksi mengalami peningkatan dari 1.058,02 ribu ton menjadi 1.650,87 ribu ton (Kementrian Pertanian, 2013: 50). Peningkatan tersebut berpotensi untuk pengembangan sel surya organik dari bahan dasar cabe.

\section{METODE PENELITIAN}

\section{Alat}

Alat-alat yang digunakan pada penelitian ini yaitu Scanning Electron Microscopy (SEM) Tescan Vega3SB, Fourier Transform Infra Red (FTIR) Shimadzu IRPrestige-21, Gas Chromatography Mass Spectroscopy (GC-MS) Thermo, Spektrofotometer Ultraviolet-Visible (UV-Vis) Shimadzu UV-2600 Series, evaporator, ultrasonik, multimeter digital, oven, neraca, hot plate, pompa vakum, kaca TCO resistensi $100 \Omega /$ sq, potensiometer dan alat-alat gelas.

\section{Bahan}

Bahan-bahan yang digunakan pada penelitian ini yaitu cabe merah (Capsiccum annum L.), titanium dioksida $\left(\mathrm{TiO}_{2}\right)$ food grade, aluminium foil, aquades $\left(\mathrm{H}_{2} \mathrm{O}\right)$, etanol $\left(\mathrm{C}_{2} \mathrm{H}_{5} \mathrm{OH}\right)$, es batu, iodin $\left(\mathrm{I}_{2}\right)$, n-heksana, kalium iodida $(\mathrm{KI})$, karbon, kertas saring, metanol $\left(\mathrm{CH}_{3} \mathrm{OH}\right)$ dan silika.

\section{Prosedur Kerja}

\section{Ekstraksi Cabe merah}

a. Ekstraksi

Cabe merah dikeringkan dan dihaluskan. sebanyak 5 gram serbuk ditimbang dan dimasukkan ke dalam gelas piala $100 \mathrm{~mL}$ lalu ditambahkan pelarut etanol sebanyak $45 \mathrm{~mL}$ dan 
diekstrasi dalam ultrasonic bath selama 25 menit. Pengerjaan diulangi dengan serbuk cabe yang lain. Fitrat ekstrak disaring dan dikentalkan dengan menggunakan evaporator dan disimpan dalam botol tidak berwarna.

b. Fraksinasi (KKCV)

Zat warna difraksinasi dengan menggunakan kolom kromatografi. Ekstrak cabe merah diimpregnasi pada silika dengan perbandingan 1:3. Rangkaian kolom silika dialiri dengan pelarut n-heksana. Komponen ekstrak difraksinasi dengan menggunakan pelarut metanol : $\mathrm{n}$ heksana (4:1), metanol : n-heksana (1:1) dan metanol : n-heksana (1:4)

\section{Preparasi DSSC}

a. Preparasi lapisan $\mathrm{TiO}_{2}$

Sebanyak 20 gram semikonduktor $\mathrm{TiO}_{2}$ (teknis) ditimbang lalu dilarutkan dengan aquadest panas kemudian didiamkan selama 30 menit dan disaring. $\mathrm{TiO}_{2}$ dicampur dengan etanol sebanyak $5 \mathrm{~mL}$ dalam gelas piala dan diaduk hingga merata.

b. Membuat elektroda TCO

Kaca TCO disiapkan dengan ukuran 2 x $2 \mathrm{~cm}$. TCO diarsir dengan ukuran $1 \times 1 \mathrm{~cm}$ dan ditutup sisi TCO dengan selotif. Semi konduktor dicetak dengan doctor blade lalu dipanaskan di atas hot plate selama 30 menit.

\section{c. Preparasi Elektrolit}

Sebanyak 0,83 gram KI ditimbang kemudian dilarutkan dengan aquades sebanyak $10 \mathrm{~mL}$. Diaduk hingga merata Selanjutnya ditambahkan 0,127 gram Iod hingga terlarut sempurna.

\section{d. Pembuatan Elektroda Pembanding}

Kaca TCO dipanaskan dengan nyala lilin hingga terbentuk lapisan berwarna hitam pada permukaannya dan pinggiran karbon dihapus sesuai dengan luas $\mathrm{TiO}_{2}$ pada elektroda

Rangkaian DSSC dibuat dengan menyusun tiap komponen dengan cara: menambahakan zat warna pada plat $\mathrm{TCO}-\mathrm{TiO}_{2}$ dengan metode penetesan dan membiarkan zat warna menyatu dengan $\mathrm{TiO}_{2}$. Larutan elektrolit beberapa tetes. diteteskan elektroda dan ditutupi dengan elektroa pembanding. Alat pengukur efisensi dirangkai yang terdiri dari dua buah multimeter dan potensiometer. Intensitas cahaya matahari diukur dengan menggunakan Luxmeter dan efisiensi ditentukan dengan cara mengatur potensiometer sehingga didapat daya maksimum.

\section{Karakterisasi Zat Warna}

Identifikasi zat warna dilakukan pada fraksi kromatografi kolom gravitasi yang memiliki efisiensi yang tertinggi setelah diuji dengan rangkaian DSSC. Instrumen karakteristik zat warna yang digunakan pada penelitian ini adalah IR, GC-MS, FTIR dan morfologi $\mathrm{TiO}_{2}$ dan zat warna diatas ITO dengan diuji dengan menggunakan SEM. 


\section{HASIL DAN PEMBAHASAN}

Pengukuran efisensi DSSC dilakukan dibawah cahaya matahari dan intensitas cahaya diukur dengan menggunakan luxmeter. Efisiensi DSSC kemudian diukur arus dan tegangan maksimum diukur dengan menggunakan dua buah multimeter dan sebuah potensiometer $20 \mathrm{k} \Omega$. Potensiometer digunakan untuk mengatur tegangan pada panel sehingga didapatkan daya maksimum. Daya yang diterima $\left(\mathrm{P}_{\text {in }}\right)$ didapatkan dari konversi nilai intensitas cahaya pada luxmeter dengan konstanta sebagai berikut:

$$
1 \mathrm{lux}=1,464 \cdot 10^{-7} \mathrm{~W} / \mathrm{M}^{2}
$$

Efisiensi DSSC dengan zat warna ekstrak cabe merah didapatkan sebesar 0,0271\% dengan daya maksimum $0,0031 \mathrm{mwatt} / \mathrm{cm}^{2}$ dan daya yang diterima $11,3182 \mathrm{mwatt} / \mathrm{cm}^{2}$. Nilai ini masih rendah jika dibandingkan dengan efisensi DSSC pada umunnya sebesar 2-3\% (Grätzel, 2001:344).

Nilai efisiensi ekstrak cabe merah setelah dilakukan fraksinasi metanol:n-heksana mengalami peningkatan. Peningkatan efisiensi DSSC setelah fraksinasi dikarenakan berkurangnya pengotor pada ekstrak cabe merah. Nilai efisiensi DSSC pada fraksi metanol: nheksana 1:4 memiliki efisensi yang tertinggi yaitu sebesar $0.0337 \%$ dengan daya maksimum $0.004364 \mathrm{mWatt} / \mathrm{cm}^{2}$ dan daya yang diterima $\left(\mathrm{P}_{\text {in }}\right)$ yaitu $12.944 \mathrm{mWatt} / \mathrm{cm}^{2}$. Peningkatan ini terjadi karena senyawa warna pada cabe didominasi oleh senyawa yang bersifat non polar. penelitian sebelumnya memperlihatkan bahwa pelarut non polar seperti THF dan heksana dapat mengekstraksi senyawa lutein dan $\beta$-karoten (Duma dan Alsina, 2012: 107). Untuk fraksi metanol: n-heksana (1:1) dan metanol:n-heksana (4:1) nilai efisensi berturut-turut $0.0127 \%$ dan $0.0122 \%$.

\section{Morfologi dan Karakterisasi Zat Warna Cabe Merah}

a. Ultra Violet Visible (UV-Vis)

Hasil Panjang gelombang dan absorbansi dari keempat puncak dapat dilihat pada Gambar di bawah

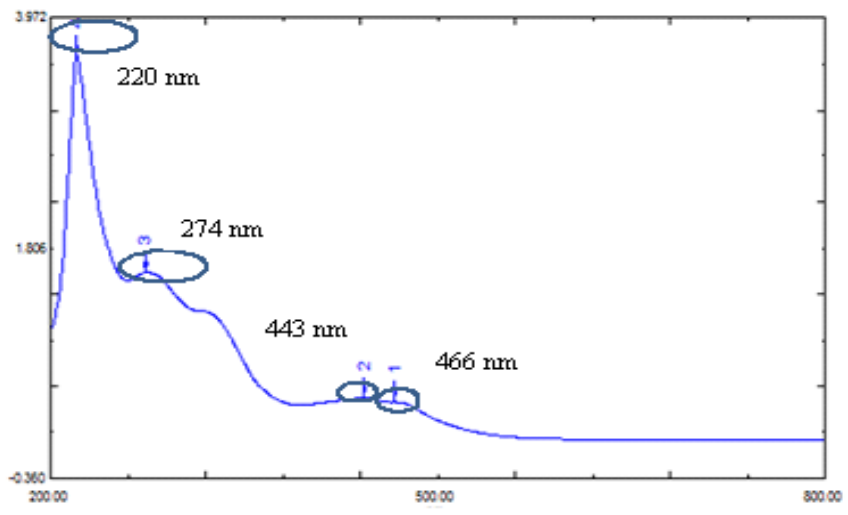

Gambar 1. Spetrum Spektrofotometer Infra Red ekstrak cabe merah hasil KKCV (metanol: N-heksana (1:4)) 
Pada Gambar 1 diatas terdapat empat puncak yang terdiri dari dua puncak pada daerah UV dan dua puncak daerah panjang gelombang cahaya tampak. Puncak pada panjang gelombang UV memperlihatkan serapan untuk ikatan $n$ yang tereksitasi menuju $\pi^{*}$ yaitu pada panjang gelombang $220 \mathrm{~nm}$ dan $274 \mathrm{~nm}$.

Selain itu, pita serapan tersebut menggambarkan bentuk dari ciri khas pita senyawa karotein. Pita serapan panjang gelombang senyawa karoten berdapat tiga puncak pada $400 \mathrm{~nm}$ hingga 600 $\mathrm{nm}$ bergantung pada jumlah ikatan rangkap yang terdapat molekul tersebut (Kevin, 2004: 59). Serapan pada panjang gelombang tampak merupakan serapan energi yang berperan pada eksitasi elektron zat warna pada DSSC.

\section{b. Fourier Transform Infrared (FTIR)}

Pengukuran Pengujian pada panjang gelombang infra merah untuk mengetahui keberadaan gugus fungsi pada zat warna tersebut, dengan demikian senyawa turunan karotein dapat diketahui. Beberapa frekuensi dan intensitas gugus fungsi pada zat warna dapat dilihat pada Gambar 2 dibawah.

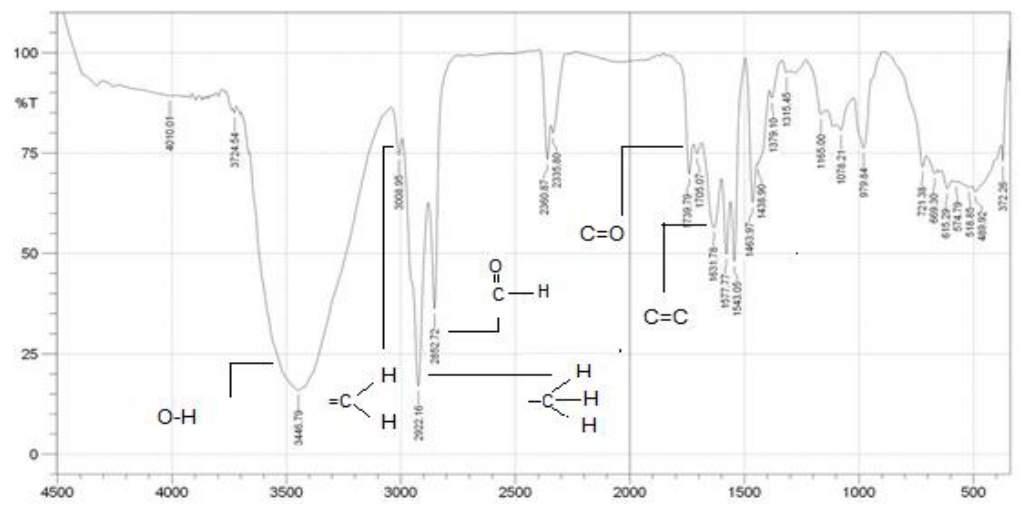

Gambar 2. Spetrum Spektrofotometer UV-Vis ekstrak cabe merah hasil KKCV (metanol: N-heksana (1:4))

Gambar diatas memperlihatkan frekuansi bilangan gelombang gugus fungsi. Bilangan gelombang $1631.78 \mathrm{~cm}^{-1}$ merupakan frekuensi gugus $\mathrm{C}=\mathrm{C}$ yang dari Selain itu, frekuensi pada bilangan gelombang $3008,95 \mathrm{~cm}^{-1}$ merupakan regangan hydrogen pada ikatan karbon tidak jenuh $(=\mathrm{C}-\mathrm{H})$ dan frekuensi $2922 \mathrm{~cm}^{-1}$ merupakan regangan untuk atom hirdrogen pada karbon jenuh (-C-H) (Brian, 1985:277-278) Ketiga frekuensi tersebut menggambarkan senyawa karoten hidrokarbon seperti $\alpha$-karoten dan $\beta$-karoten.

Selain itu senyawa turunan karotenoid dengan gugus hidrokarbon terdapat pula frekuensi yang menyatakan keberadaan senyewa xantofil. Frekuensi $1739 \mathrm{~cm}^{-1}$ merupakan frekuensi regangan untuk gugus karbonil $(\mathrm{C}=\mathrm{O})$. Senyawa karotein yang memiliki gugus karbonil adalah capsantin dan astaxantin (Brian, 1985: 59). Gugus heteroatom hidroksil juga terdapat pada zat warna tersebut dengan serapan pada bilangan gelombang $3446.79 \mathrm{~cm}^{-1}$. Senyawa karotenoid dengan gugus hidroksil misalnya lutein . 


\section{c. Gas Chromatography-Mass Spectroscopy (GC-MS)}

Adapun hasil GC-MS dapat dilihat pada Gambar 3 di bawah ini:

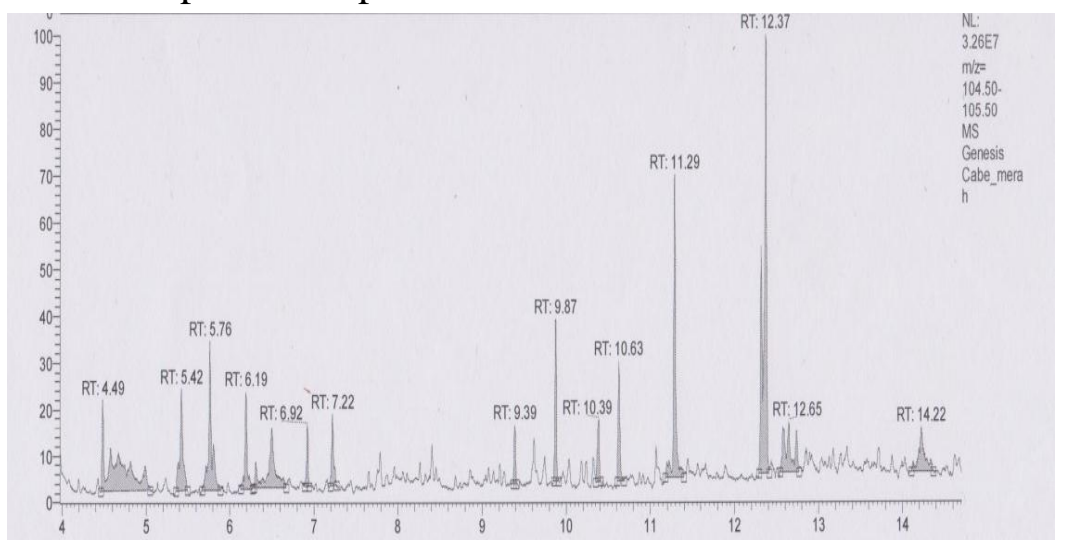

Gambar 3. Kromatogram Ekstrak Cabe Merah Metanol:n-Heksana (1:4)

Gambar diatas memperlihatkan kromatogram ekstrak cabe merah dan didapatkan fragmentasi karotenoid pada retensi 9.87 menit. Fragmentasi karotenoid dapat dilihat pada gambar dibawah:

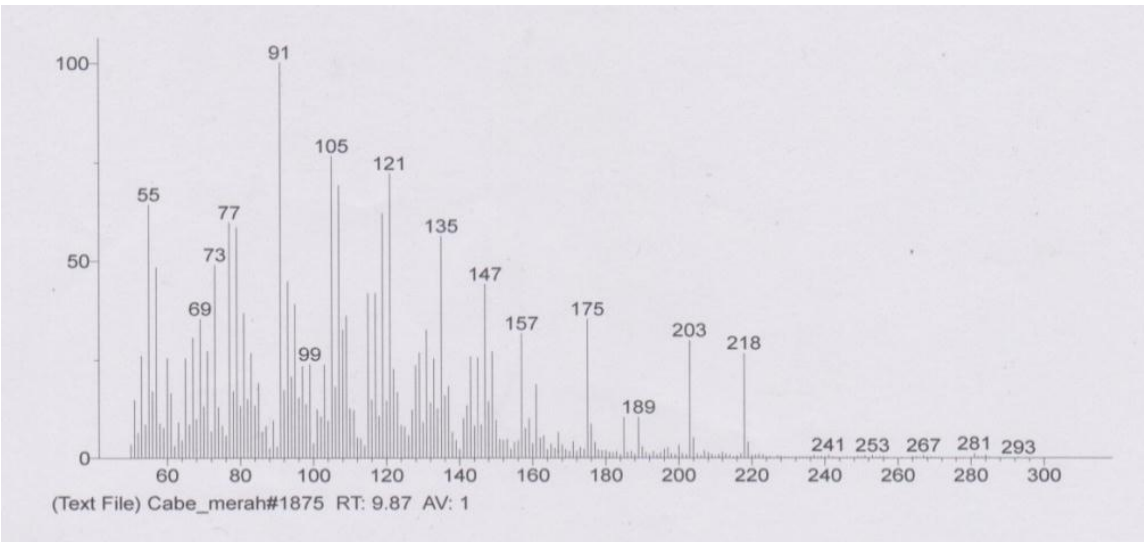

Gambar 4. Fragmen berat molekul ekstrak cabe merah hasil KKCV (metanol: N-heksana (1:4)) pada retensi 9.87 menit

Gambar diatas memperlihatkan fragmen ion pada retensi 9.87 menit dengan kelimpahan ion molekul m/z 91 yang tertinggi. Ion khas dari senyawa karoten adalah 92 dan 106 dari senyawa toluen $\left(\mathrm{C}_{7} \mathrm{H}_{8}\right)$ dan xilena $\left(\mathrm{C}_{8} \mathrm{H}_{10}\right)$ ion $\mathrm{M}+1$ dari molekul tersebut (Kevin, 2004: 321). Senyawa pada ion molekul pada berat molekul 91 dan 105 dapat juga merupakan fragmen senyawa isopren dari senyawa karotenoid.

Senyawa ion $\mathrm{C}_{7} \mathrm{H}_{7}^{+}$merupakan senyawa ion tropilium yang stabil (Brian, 1985:369) sehingga pada ion ini berada pada kelimpahan terbesar sebesar $100 \%$ merupakan ciri dari ion 
molekul lutein (Enzel dan Francis, 1969:736). Ion molekul selanjutnya pada retensi ini yaitu ion molekul m/z 105 merupakan ion molekul $\mathrm{C}_{8} \mathrm{H}_{9}{ }^{+}$dan berat ion molekul dengan m/z 121 adalah ion $\mathrm{C}_{9} \mathrm{H}_{13}{ }^{+}$.

\section{e. Morfologi zat warna padaTiO}

Analisis morfologi zat warna padaTiO ${ }_{2}$ dapat menjelaskan hubungan ikatan antara zat warna dan $\mathrm{TiO}_{2}$. Interaksi zat warna pada $\mathrm{TiO}_{2}$ dapat dilihat pada gambar di bawah.
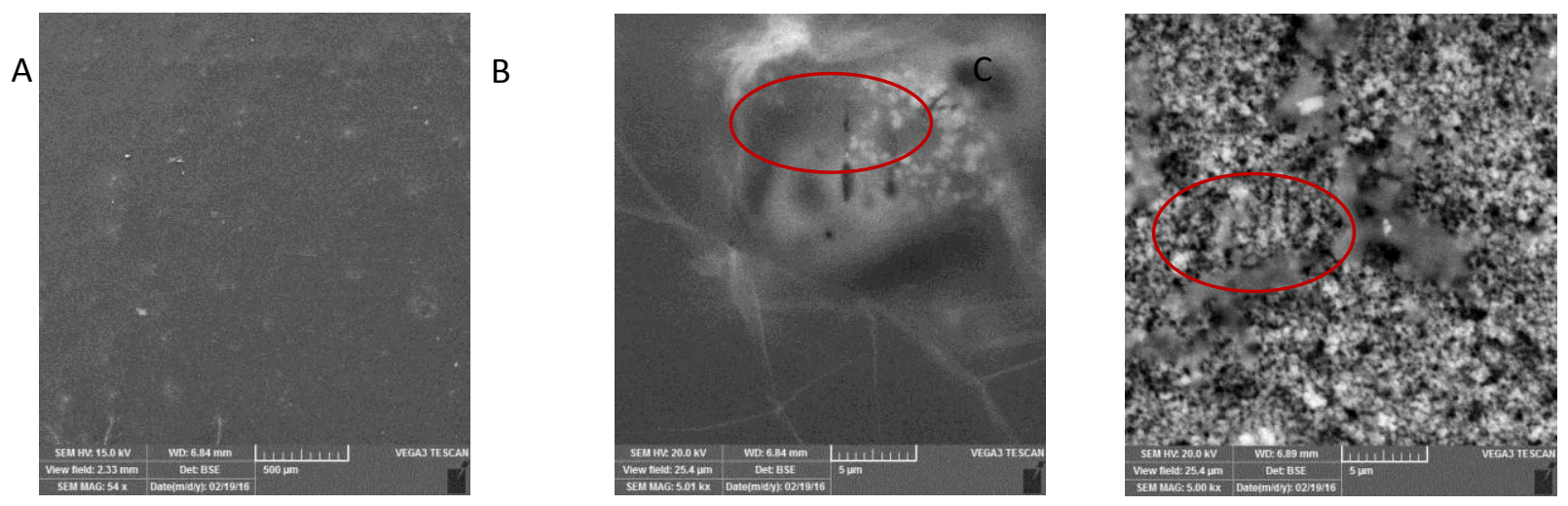

Gambar 5 A. morfologi $\mathrm{TiO}_{2}$ teknis yang dilapisi zat warna perbesaran $500 \mu \mathrm{m}$; B. Morfologi $\mathrm{TiO}_{2}$ teknis yang dilapisi zat warna perbesaran $5 \mu \mathrm{m}$ dan C. Morfologi $\mathrm{TiO}_{2}$ teknis yang dilapisi zat warna perbesaran $5 \mu \mathrm{m}$.

Gambar diatas merupakan morfologi dari zat warna pada $\mathrm{TiO}_{2}$ yang terlihat menggunakan SEM. Gambar A merupakan morfologi yang pada ukuran $500 \mu \mathrm{m}$ dan terlihat jelas zat warna menuntupi pori dari $\mathrm{TiO}_{2}$. Gambar B memperlihatkan beberapa butiran $\mathrm{TiO}_{2}$ yang tertutupi zat warna sedangkan gambar $\mathrm{C}$ merupakan morfologi $\mathrm{TiO}_{2}$ dengan pori yang terbuka dan zat warna yang telihat jelas pada bagian $\mathrm{TiO}_{2}$ yang terlihat buram. Hal ini sesuai dengan hasil penelitian yang dilakukan oleh Alwani,dkk (2015:136) dan Wahab dkk (2015: 43-51) yang memperlihatkan morfologi $\mathrm{TiO}_{2}$ dengan dan tanpa zat warna. Zat warna pada $\mathrm{TiO}_{2}$ dideteksi dengan adanya penggumpalan $\mathrm{TiO}_{2}$ yang dikarenakan adanya sebaran zat warna yang tidak merata.

\section{PENUTUP}

Zat warna yang diperoleh dari fraksi metanol-n heksana 4:1 memberikan nilai efisiensi $0,034 \%$. Nilai ini relatif masih rendah dibandingkan nilai efisiensi sel surya berbasis zat warna anorganik. Komponen utama fraksi ini diduga golongan senyawa karotenoid. 


\section{DAFTAR PUSTAKA}

Al-Alwani, dkk. 2015. Effect of Solvents on Extraction of Natural Pigments and Adsorpsion onto $\mathrm{TiO}_{2}$ for Dye-Sensitized Solar Cell Applications". Spectrochimica Acta Part A: Molecular and Biomolecular Spectroscopy 135: 130-137.

Davies, Kavin. 2004. Plant pigment and Their Manipulation. New Zealand: Blackwell Publishing,

Dewan Energi Nasional Republik Indonesia”Outlook Energi Indonesia” 2014

Gracia, Maria del Rocio Gomes, dkk. 2013.Biochemistry And Molecular Biology Of Carotenoid Biosynthesis In Chili Peppers (Capsicum Spp). International Journal of Molecular Sciences 14(9): 19025-19053.

Grätzel, Michael. 1991 . A low-cost, high-efficiency solar cell based on dye-sensitized colloidal $\mathrm{TiO}_{2}$ films Nature 353: 737-740

Kementrian pertanian Republik Indonesia”Laporan Data Kinerja” 2013.

Lim, Anderly. 2015. "Potential Natural Sensitizer Extracted from the Skin of Canarium Odontophyllum Friut for Dye-Sensitizer Solar Cell”. Molecular and Biomolecullar Spectrofotometer 138: 596-602.

Mara Duma dan ina Alsina. "The Content of Plant Pigment in Red and Yellow Bell Peppers". Scintific Pappers 56 (2012).

Underwood A.L. dan DayR.A. Quantitative Analysis. Terj. Iis Sofian. Analisis Kuantitaif Edisi ke Enam. Jakarta : Erlangga . 1999.

Yahya, Harun. 2003. The Creation of The Universe. terj. Ary Nilandri, Bandung, Dzikra.

Wahab, Hasbi N., Aisyah, Suriani, Iswadi, 2016. Karakterisasi Zat Warna Tomat (Solanum Lycopersicum) Fraksi Metanol:N-Heksan Sebagai Photosensitizer Pada Dye Sensitized Solar Cell (DSSC). Al-Kimia, 4(2): 43-51. 